\title{
A RE-EXAMINATION OF DITHYRIDIUM CYNOCEPHALI RANSOM 1905, A METACESTODE PARASITE FROM THE THYLACINE THYLACINUS CYNOCEPHALUS
}

\author{
by David L. Obendorf and Steven J. Smith
}

(with one table and one plate)

OBENDORF, D.L. \& SMITH, S.J., 1989 (31:x): A re-examination of Dithyridium cynocephali Ransom 1905, a metacestode parasite from the thylacine Thylacinus cynocephalus. Pap. Proc. R. Soc. Tasm. 123: 133-136.

https://doi.org/10.26749/rstpp.123.133 ISSN 0080-4703. Tasmanian Department of Agriculture, PO Box 46, Kings Meadows, Tasmania 7249 (DLO); and Tasmanian Department of Lands, Parks \& Wildlife, GPO Box 44A, Hobart, Australia 7001 (SJS).

Re-examination of Dithyridium cynocephali Ransom 1905, a metacestode parasite from the thylacine Thylacinus cynocephalus, has revealed it to be morphologically indistinguishable from metacestodes of the tapeworm Anoplotaenia dasyuri found in the eastern quoll Dasyurus viverrinus and the spotted-tailed quoll D. maculatus, in Bennett's wallaby Macropus rufogriseus rufogriseus and in the Tasmanian pademelon Thylogale billardierii. The Tasmanian devil Sarcophilus harrisii is the predominant definitive host for $A$. dasyuri, but the two quoll species can also serve as definitive hosts. It is considered likely that quolls may act as intermediaie hosts through the occasional consumption of Tasmanian devil faeces containing infective A. dasyuri eggs. The thylacine may have become infected with A. dasyuri in a similar manner, by engaging in coprophagy in the wild or in captivity.

Key Words: thylacine, Anoplotaenia dasyuri, metacestodes, coprophagy, Dithyridium cynocephali.

\section{INTRODUCTION}

On 4 November 1904, a mature female thylacine Thylacinus cynocephalus died at the National Zoological Park in Washington, D.C., U.S.A. At the necropsy performed at the National Museum “... encysted larval forms of a tapeworm were found in all the muscular structures of the body". Ransom (1905) published a brief report of the larval cestode recovered from the heart and skeletal muscles of the animal and named the parasite Dithyridium cynocephali. Fortunately, specimens of the parasite were also lodged in the National Parasite Collection (NPC) of the United States Department of Agriculture. When metacestodes were recently found in the heart and skeletal muscles of eastern quolls Dasyurus viverrinus and spotted-tailed quolls D. maculatus from Tasmania's northwestern highlands, a re-examination of the parasite from the thylacine was undertaken. The only other parasites recorded from the thylacine are the endemic Tasmanian flea Uropsylla tasmanica (Dunnet \& Mardon 1974) and the ascaridoid nematode Ascaridia columbae (Sprent 1972).

\section{MATERIALS AND METHODS}

For this study, the original slides of serial-sectioned Dithyridium cynocephali (NPC No.3888) and several additional sections prepared at Mount Pleasant Laboratories, Launceston, from alcoholpreserved specimens were examined. These specimens were compared with metacestodes obtained from the hearts of naturally-infected Bennett's wallabies Macropus rufogriseus rufogriseus and Tasmanian pademelons Thylogale billardierii. Metacestodes recovered from two eastern quolls Dasyurus viverrinus and four spotted-tailed quolls D. maculatus from the Cradle Mountain region were also examined. In addition to this material, a metacestode found in masseter muscle from an alcohol-preserved thylacine skull (NMV C5752) from the Museum of Victoria was also examined.

All preserved specimens and muscle tissues were prepared for microscopic examination using routine histological techniques. Specimens were dehydrated through increasing concentrations of ethyl alcohol, paraffin embedded and sectioned at a thickness of $5 \mu \mathrm{m}$. Sections were placed on glass slides, stained with haematoxylin and eosin, and examined with a light microscope. Measurements of various parts of the metacestodes were taken using an ocular micrometer.

Histological sections of metacestodes from eastern quoll, spotted-tailed quoll and thylacine have been lodged on slides in the Australian Helminth Collection (AHV18680, AHC18681, AHC18682 \& AHC18683). Samples of preserved 
infected muscle tissue from thylacine and spottedtailed quoll have been lodged in the same collection (AHC18684 \& AHC18685).

\section{RESULTS AND DISCUSSION}

Although somewhat faded, the original mounted specimens from the thylacine (NPC No.3888) had sufficient clarity and contrast for proper examination. Freshly-prepared sections of metacestodes from this thylacine stained more intensely, but the age of the specimens caused the differential staining properties of the haematoxylin and eosin dyes to be suboptimal.

The metacestodes from the thylacine were morphologically indistinguishable from those recovered from two extant dasyurids $D$. viverrinus and $D$. maculatus, and two macropods $M . r$. rufogriseus and $T$. billardierii. In all hosts, metacestodes were circular to ovoid and were contained within a fibrous connective tissue capsule produced by the host tissues. In skeletal muscle tissues they were generally aligned with muscle fibres, and fat tissue was present at each pole of the outer fibrous capsule. They had a thick cuticle or tegument and an underlying muscle system; numerous cell bodies were arranged in a dense aggregate under the cuticle, adjacent to the muscles. The body of the parasite consisted of open parenchyma in which cell nuclei were scattered; a distinctive characteristic of the parenchyma was the presence of numerous calcareous corpuscles. The scolex was unarmed and invaginated into the body of the metacestode, the invaginated portion being lined by cuticle and containing four suckers. The cuticle in these areas was very thick and overlaid large numbers of cell nuclei. In some specimens from all hosts a small bladder or vesicle was seen in the posterior pole of the metacestode; several showed an osmoregulatory canal consisting of a tubular invagination lined. with cuticle and measuring 80 to $210 \mu \mathrm{m}$ in length. The dimensions of the whole metacestode, the suckers and the cuticle thickness of various specimens from the thylacine (NPC No.3888), the two quoll species and the two macropods are presented in table 1.

The metacestodes recovered from the two macropods are typical of the intermediate host stage of the tapeworm Anoplotaenia dasyuri. All those examined and described in this study are similar to $A$. dasyuri metacestodes originally described from experimentally infected mice (Beveridge et al. 1975) and to those from naturally infected Tasmanian marsupials (Gregory et al. 1975). The only difference in the description of metacestodes from experimentally and naturally infected marsupials was the absence of a posterior bladder or vesicle in metacestodes from the laboratory mice. This difference was not considered significant, as the feature also appeared to be variable in specimens from naturally infected hosts.

Ransom (1905), in his original report, considered that the larval cestodes in the thylacine were probably derived from a comparatively recent infection acquired through ingestion of infective tapeworm eggs at the Zoological Park in Washington. Re-examination of this museum material and its comparison with metacestode infections of $A$. dasyuri in $M$. r. rufogriseus and

TABLE 1

\section{Dimensions of the Metacestodes from Various Hosts}

\begin{tabular}{|c|c|c|c|c|c|}
\hline \multirow[t]{2}{*}{ Host } & \multicolumn{2}{|c|}{ Metacestode* } & \multicolumn{2}{|c|}{ Suckers* } & \multirow{2}{*}{$\begin{array}{c}\text { Cuticle } \\
\text { thickness* } \\
\text { mm }\end{array}$} \\
\hline & $\begin{array}{c}\text { length } \\
\text { mm }\end{array}$ & $\begin{array}{c}\text { width } \\
\text { mm }\end{array}$ & $\begin{array}{c}\text { length } \\
\text { mm }\end{array}$ & $\begin{array}{c}\text { width } \\
\text { mm }\end{array}$ & \\
\hline Thylacinus cynocephalus & $\begin{array}{c}652 \\
(430-880)\end{array}$ & $\begin{array}{c}343 \\
(220-380)\end{array}$ & $\begin{array}{c}162 \\
(107-182)\end{array}$ & $\begin{array}{c}113 \\
(90-164)\end{array}$ & $(3.8-6.5)$ \\
\hline Dasyurus spp. & $\begin{array}{c}654 \\
(400-930)\end{array}$ & $\begin{array}{c}349 \\
(230-460)\end{array}$ & $\begin{array}{c}148 \\
(139-165)\end{array}$ & $\begin{array}{c}109 \\
(78-139)\end{array}$ & $\begin{array}{c}4.5 \\
(3.2-5.5)\end{array}$ \\
\hline $\begin{array}{l}\text { Macropus r. rufogriseus } \\
\text { Thylogale billardierii }\end{array}$ & $\begin{array}{c}487 \\
(370-560)\end{array}$ & $\begin{array}{c}266 \\
(215-315)\end{array}$ & $\begin{array}{c}138 \\
(115-150)\end{array}$ & $\begin{array}{c}66 \\
(60-75)\end{array}$ & $\begin{array}{c}5.5 \\
(4.1-6.2)\end{array}$ \\
\hline
\end{tabular}

*Mean measurements of ten specimens, range in parenthesis. 
T. billardieril suggest that the parasite reported from this captive thylacine is almost certainly the endemic Tasmanian parasite A. dasyuri (pl, 1). At the time of the recovery of this parasite from the thylacine and its subsequent naming by Ransom (1905), A. dasyuri was unknown and its indirect life cycle was not elucidated until relatively recently (Gregory et al. 1975).

Anoplotaenia dasyuri is an abundant parasite in Tasmania, maintained through a carnivore-carrion feeding association involving the Tasmanian devil Sarcophilus harrisii as definitive host and certain macropod species as intermediate hosts (Gregory et al. 1975). Adult tapeworms occur in the small intestines of Tasmanian devils, and metacestode stages are found in the hearts, lungs and skeletal muscles of macropods, principally $M$. r. rufogriseus and $T$. billardierii. These herbivorous macropods acquire infection through the ingestion of herbage containing infective Anoplotaenia eggs. The prevalence of $A$. dasyuri infection in Tasmanian devils is very high: $99 \%$ (293 of 294) in one survey (Gregory et al. 1975) and 98\% (87 of 88 ) in another carried out by one of the authors (DLO) in 1988. In addition, the large numbers of gravid tapeworms found in Tasmanian devils, the relatively short prepatent period (less than 85 days - Gregory et al. 1975) and the high density of Tasmanian devils in many areas of Tasmania (Green 1968, Guiler 1970) ensure a widespread distribution of eggs in the environment and a high level of exposure to infection for the intermediate hosts.

Tasmanian devils are the predominant definitive hosts of $A$. dasyuri, but both $D$. viverrinus and $D$. maculatus are also known to harbour small numbers of immature and sometimes gravid worms (Gregory et al. 1975, DLO, unpubl. observations). Differences between the feeding habits of quolls and Tasmanian devils are likely to reduce the exposure of quolls to adult $A$. dasyuri infection. Eastern quolls eat insects in large quantities when available, but also prey on ground-nesting birds and small mammals. Spotted-tailed quolls are opportunistic predators of a variety of birds, rodents, other arboreal and terrestrial small mammals, reptiles and invertebrates. Both species of quoll will scavenge carrion of large mammals, but Tasmanian devils are thought to be more successful scavengers for any that is available (Strahan 1983).

The finding of numerous metacestodes of A. dasyuri in both species of quoll in the Cradle Mountain region was unexpected; it seems likely that they are accidental intermediate hosts of $A$. dasyuri. Access to infective Anoplotaenia eggs could occur if quolls consumed either herbage containing eggs or the faeces of the Tasmanian devil; the relatively high levels of infection by metacestodes indicate that the latter is more likely. Another possibility for transmission to the quolls is that invertebrates (such as insects and earthworms), associated with soil, herbage or faeces, are involved as mechanical vectors of Anoplotaenia eggs. Anoplotaenia dasyuri has not, however, been recorded in the two species of bandicoot in Tasmania, Perameles gunnii and Isoodon obesulus, both of which eat large quantities of these invertebrates.

All of the quolls with metacestode infections were old or injured, with worn or missing teeth, foot injuries or arthritic problems; such debilitated individuals are likely to be less successful predators and carrion feeders. This factor, combined with the

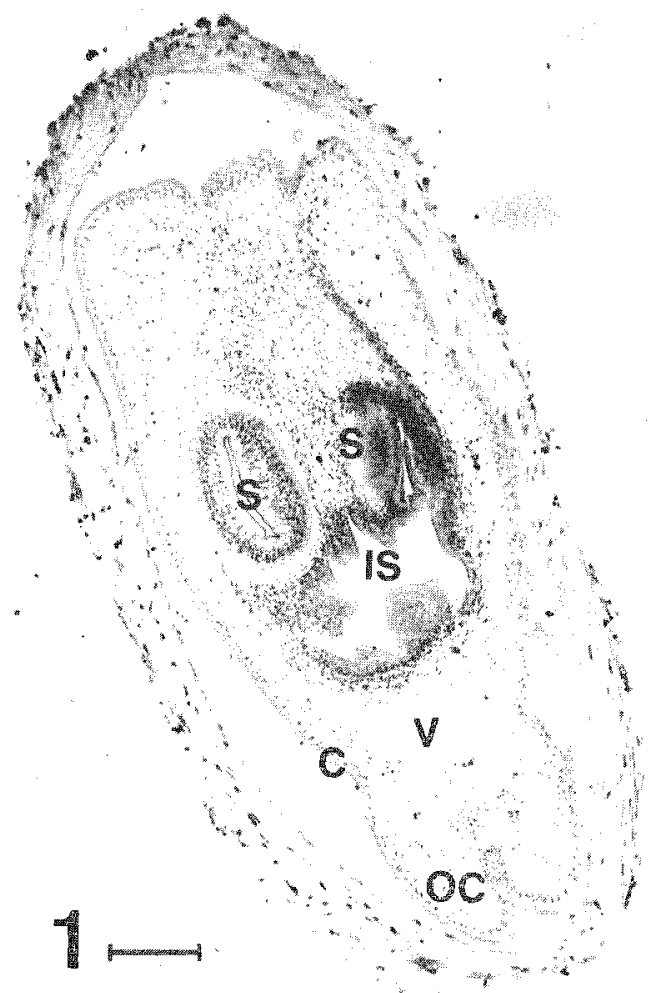

PLATE I

Photomicrograph of an encysted metacestode dissected from the skeletal muscles of Thylacinus cynocephalus (NPC No. 3888).

$C=$ cuticle, $S=$ suckers, $V=$ vesicle, $O C=$ osmoregulatory canal, $I S=$ invaginated scolex. Scale bar $=0.1 \mathrm{~mm}$. 
winter depletions in food availability (absence of insects and migration of many species of birds) in the highlands, may occasionally force these quolls to adopt coprophagic feeding habits. It is conceivable also that the thylacine held in captivity in the USA may have acquired its infection in Tasmania prior to capture or through close contact with devils whilst held in zoos either in Tasmania or the USA. In the case of the thylacine specimen from the Museum of Victoria (NMV C5752), the original correspondence accompanying this material confirms that the animal was shot in the wild. The discovery of a free-ranging thylacine with metacestode infection suggests that this large carnivorous marsupial was capable of acting as an intermediate host for $A$. dasyuri, as do the quolls today.

It is not known whether the thylacine was capable of harbouring adult infections of $A$. dasyuri. The preserved stomach and intestines of four thylacines held at the Australian Academy of Science in Canberra were examined by Sprent (1971). No intestinal cestodes were found. Subsequent enquiries made by Sprent failed to find any further parasites in museum collections in Europe, the USA and Australia.

Maintenance of A. dasyuri in Tasmania has relied on successful co-evolution of the parasite within a natural carnivore-herbivore feeding association. Little information on the dietary preferences of free-ranging thylacines is available (Smith 1980, Guiler 1985, Dixon 1989). However, one might suspect that a close "predator prey" relationship existed between thylacines and native macropods similart to that between Tasmanian devils and macropods. The results of this study, however, suggest that the thylacine differs from the Tasmanian devil in that the former is capable of sustaining metacestode infections of $A$. dasyuri, whilst no such larval stage infections have been reported in the latter. In this respect, the host-parasite relationship between the thylacine and $A$. dasyuri is similar to that occurring with the two species of quoll. This observation may suggest that the thylacine was not an important definitive host of $A$. dasyuri.

The metacestodes of Dithyridium cynocephali and Anoplotaenia dasyuri are indistinguishable and the parasites are probably the same species. There are many cestode species, however, that have obviously different adults but indistinguishable metacestodes. The authors have not formally suppressed either of the scientific names, as it cannot be experimentally demonstrated that the adult of the cestode in the thylacine and in the spotted-tailed quoll are the same.

\section{ACKNOWLEDGEMENTS}

We wish to thank Dr R. Lichtenfels, Curator of the U.S. National Helminth Collection, Beltsville, Maryland for loaning the type material of Dithyridium cyanocephali (NPC No.3888), Ms J. Dixon, Curator of Manmals, Museum of Victoria, Melbourne, Victoria, for providing the additional thylacine masseter muscle for examination (NMV C5752), and Mr G. Veldhuis and Ms J. Deavin for histological preparation of the specimens.

\section{REFERENCES}

Beveridge, I., Rickard, M.D., Gregory, G.G. \& MUNDaY, B.L., 1975: Studies on Anoplotaenia dasyuri Beddard 1911 (Cestoda:Taeniidae), a parasite of the Tasmanian devil: Observations on the egg and metacestode, Int. J. Parasitol. 5: 257-267.

DixON, J.M., 1989: Thylacinidae. In FAUNA OF AUSTRALIA, Vol.l(b). Bureau of Flora and Fauna, Canberra: chapter 20.

Gregory, G.G., Munday, B.L., Beveridge, I. \& RICKARD, M.D., 1975: Studies on Anoplotaenia dasyuri Beddard 1911 (Cestoda:Taeniidae), a parasite of the Tasmanian Devil: Life cycle and epidemiology. Int. $J$. Parasitol. 5: 187-191.

DunNet, G.M. \& Mardon, D.K., 1974: A monograph of Australian fleas (Siphonaptera). Aust. J. Zool. Suppl. Ser. No.30.

Green, R.H., 1968: Notes on the Devil (Sarcophilus harrisil) and the quoll (Dasyurus viverrinus) in Northeastern Tasmania. Rec. Q. Vict. Mus. 27: 1-13.

Guiler, E.R., 1970: Observations on the Tasmanian Devil, Sarcophilus harrisii (Marsupalia:Dasyuridae) I. Numbers, home range, movements and food in two populations. Aust. J. Zool. 18: 49-62.

GulLER, E.R., 1985: THYLACINE: THE TRAGEDY OF THE TASMANIAN TIGER. Oxford University Press, Melbourne.

Ransom, B.H., 1905: Tapeworm cysts (Dithyridium cynocephali n.sp.) in the muscles of the Tasmanian Wolf (Thylacinus cynocephalus). Am. Microscop. Soc. Trans. 27: $31-32$.

Smith, S.J., 1980: The Tasmanian Tiger. Wildl. Division Tech. Rep. 81/1. Tasm. NPWS.

SPRENT, J.F.A., 1971: A new genus and species of Ascaridoid nematode from the marsupial wolf (Thylacinus cynocephalus). Parasitology 63: 37-43.

Sprent, J.F.A., 1972: Cotylasiaris thylacini, a synonym of Ascaridia columbae. Parasitology 64(2): 331-332.

Strahan, R.E., 1983: COMPLETE BOOK OF AUSTRALIAN MAMMALS. The Australian Museum, Angus \& Robertson, Sydney.

(accepted 1 June 1989) 